\title{
Lições de dança na mídia
}

\author{
Dance lessons at the media
}

\author{
Lecciones de danza en los medios
}

\begin{abstract}
AIRTON TOMAZZONI*
$\diamond$

RESUMO - Este artigo busca sintetizar aspectos desenvolvidos na tese Lições de dança no baile da pós-modernidade - corpos (des)governados na mídia, expondo delineamentos pedagógicos no cenário midiático contemporâneo. A perspectiva dos Estudos Culturais em seu cruzamento com a Educação inspirou as opções teorico-metodológicas que pemitiram avançar na articulação do conceito de midiatização e de como este possibilita a operação de estratégias de construção de sujeitos e de seu governamento. Para tal entendimento foi fundamental a contribuição dos conceitos de poder e dispositivo trazidos por Michael Foucault e Gilles Deleuze. O estudo debruçou-se sobre um corpus composto por filmes, videoclipes, sites da internet, revistas, jornais, brinquedos eletrônicos, programas de televisão, entre outros. A análise permitiu perceber dez lições que se esboçam de maneira recorrente na mídia, operando na configuração de sujeitos dançantes, em políticas de gestão da vida, tanto promovendo o gerenciamento de singularidades, como a potencialização de novos modos de ser e estar no mundo contemporâneo.
\end{abstract}

Palavras-chaves - Dança e educação. Mídia e educação. Lições de dança.

\begin{abstract}
This paper seeks to synthesize aspects developed in the thesis Dance lessons at the dance of postmodernity - bodies controls in the media, exposing pedagogical contemporary media practices. The perspective of Cultural Studies and its follow-ups in Education were methodological and theoretical options which made possible to advance towards the articulation of the concept of mediatization and how this process allows the operation of strategies of subjectification and government was pursued. The contributions of Michel Foucault and Gilles Deleuze were vital to such understanding, particularly the concept of power and dispositif. In order to proceed such analysis a plural corpus was assumed: movies, video clips, sites, magazines, electronic toys and television programs among others. It was possible to set ten lessons that are recurrently delineated in media, which operate on the constitution of the dancing subjects, on life management policies, by promoting not only the management of singularities, but also the maximization of new ways of being and living in the contemporary world.
\end{abstract}

Keywords - Dance and education. Media and education. Dance lessons.

RESUMEN - Este artículo busca sintetizar aspectos desarrollados en la tesis Lecciones de danza en el baile de la postmodernidad - cuerpos (des)gobernados en los medios, exponiendo delineaciones pedagógicas en el escenario mediático contemporáneo. La perspectiva de los Estudios Culturales en su cruce con la Educación inspiró las opciones teórico-metodológicas que permitieron avanzar en la articulación del concepto de mediatización y de cómo éste hace posible la operación de estrategias de construcción de sujetos y de su gobernación. Para tal entendimiento fue fundamental el aporte de los conceptos de poder y dispositivo traídos por Michel Foucault y Gilles Deleuze. El estudio se inclinó sobre un corpus compuesto por películas, videoclips, páginas de internet, revistas, periódicos, juguetes electrónicos, programas de televisión, entre otros. El análisis permitió percibir diez lecciones que se bosquejan de manera recurrente en los medios, operando en la configuración de sujetos bailantes, en políticas de gestión de la vida, tanto promoviendo la gerencia de singularidades como la potenciación de nuevos modos de ser y estar en el mundo contemporáneo.

Palavras clave - Danza y educación. Medios y educación. Lecciones de danza.

\footnotetext{
* Doutor em Educação pela Universidade Federal do Rio Grande do Sul (Porto Alegre, RS, Brasil) e professor da Escola Livre de Dança, Prefeitura Municipal de Porto Alegre (Porto Alegre, RS, Brasil).E-mail: <airtontomazzoni@gmail.com>.
} 
OCORRÊNCIA 1: Em uma loja de doces, um jovem pergunta para uma senhora septuagenária se ela tem talento. A senhora coloca uma fita cassete pra tocar, sai detrás do balcão e dança um insinuante e requebrante funk enquanto a letra diz: "Sou tchutchuca, sou gatinha, faça chuva ou faça vento. Você vem me dá bom dia e eu te encho de talento. Vem, vem, que eu te encho de talento."

Propaganda da Garoto para o Chocolate Talento, veiculada na programação de televisão de 2007 e 2008.

Uma senhora que, ao ser solicitada a mostrar seu talento, não vacila em dançar um insinuante funk para um jovem e belo rapaz. Ocorrências como estas desencadearam inquietações que delinearam os contornos iniciais desta pesquisa. Um filme que transforma, com a dança, a realidade de jovens da periferia. Videoclipe com música que convoca todos a dançar, enquanto exibe crianças brincando de imitar coreografias de ícones do pop, como John Travolta e Michael Jackson. Um ator que, por um concurso de dança na televisão, ganha a fama e o reconhecimento que não conseguiu atuando em novelas. Um clique no mouse que desvenda os passos para se dançar forró. Diversão e brincadeiras eletrônicas que viram uma espetacular performance de dança nos shoppings centers.

Cenas como essas sinalizam para algumas especificidades que a dança vem apresentando no território midiático. ${ }^{1}$ Às crianças, aos jovens, ao galã, à esportista, ao comediante, à velhinha é solicitado que mostrem seu talento para a dança, que entrem no ritmo, que requebrem, que seduzam, que se divirtam. E pode ser em qualquer lugar, a qualquer hora e em muitos estilos. Alguns podem se perguntar: mas isso os musicais de Hollywood também faziam? E certamente faziam, mas nos musicais, salvo exceções, quem dançava eram em sua maioria adultos brancos. Não me recordo de nenhuma velhinha ao lado de Fred Astaire (ainda que duas setuagenárias aceitem, constrangidas, bailarem com Gene Kelly, em Sinfonia em Paris) ou em nenhum solo de dança antológico. E, tirando Shirley Temple, poucas meninas também apareciam, assim como pouco apareciam jovens negros, latinos, asiáticos ou gays. E, muito menos, os protagonistas dançavam funk, hip hop, discoteca ou gafieira.

Além disso, no que se refere ao público, ele só se deliciava ou se irritava com dança quando decidia ir ao cinema. Havia hora e lugar para a dança poder aparecer. Com o advento da televisão e da internet, nota-se a inserção mais ampla e radical da dança midiaticamente, a singularidade destes novos lugares que ela passa a habitar e novos modos de interação que passa a operar.

Percebem-se essas mudanças que a mídia promove no vocabulário de muitas danças que acabam ganhando espaço de circulação, espalhando-se rapidamente para além dos territórios geográficos de origem, como o hip hop e o funk das periferias. Por sua vez, na esfera do consumo as fronteiras entre o dito erudito e popular são minadas, assim como os limites que separam tribos, classes e gêneros são borrados. Percebe-se que nesse contexto, certas lições de dança começam a se delinear e nesse artigo faço um movimento sintético para trazer aspectos centrais de uma pesquisa mais ampla intitulada Lições de dança no baile da pós-modernidade - corpos (des)governados na mídia, tese de doutoramento defendida no Programa de Pós-Graduação em Educação da UFRGS.

\begin{abstract}
OCORRÊNCIA 2: "Ele deixou de ser apenas o namorado bonitão da atriz Fernanda Lima. Agora ele é o namorado bonitão da atriz Fernanda Lima e um dançarino famoso. Rodrigo Hilbert, 27 anos, venceu a quarta edição do Danças dos Famosos."

Trecho da matéria de capa do $T V+$ Show do jornal Zero Hora, de 24 jun. 2007.
\end{abstract}

Neste baile, a mídia espetaculariza e glamouriza a dança e, consequentemente, quem dança. Se num passado recente "ser dançarina" era sinônimo de prostituição, e "ser dançarino", de afeminação (para os homens) e desvalorização social, hoje, dançar pode garantir prêmio em dinheiro, sucesso, fama, ou ainda o consolo de estar colaborando para soluções dos problemas sociais do país, da sua cidade ou do seu bairro.

A sensação de que a dança vinha ganhando na e com a mídia um novo e diferente relevo foi se alinhavando com estas percepções e por uma coleção de cenas nas quais eu "tropeçava" diariamente e que iam ampliando meu universo de pesquisa. Eu ligava a televisão e "pimba", lá surgia uma coreografia num filme ou mesmo num desenho animado. Eu abria o jornal e acompanhava a estreia de mais um filme com a temática da dança como central. Era entrar na internet e alguém me havia mandado uma animação do Homem-Aranha dançando uma música disco. Era ir a uma festa e acabava discutindo com amigos (que não são coreógrafos, nem bailarinos) quem tinha sido melhor na Dança dos Famosos. E, para completar, se eu precisava encontrar um trecho de um balé de repertório do século XIX, entrava no YouTube e pronto, podia assistir a ele. A mídia se mostrava para mim como uma grande "sala de aula" na qual a dança vinha aparecendo em "lições" frequentes e repetidas.

OCORRÊNCIA 3: Numa tarde de outono de 2007, na área de diversões eletrônicas do Shopping Iguatemi, de Porto Alegre, dois adolescentes disputam quem consegue a maior pontuação seguindo os passos e a música do Pump It Up!, sob o olhar de uma atenta plateia de outros adolescentes ao redor. 
Estas novidades vêm modificando significativamente o modo de a dança estar inserida em nossa cultura, trazendo uma série de possibilidades e, com elas, desafios. Eu podia deparar-me com tal quadro na dificuldade de alunos e alunas do curso de licenciatura em dança, quando precisam planejar uma aula de dança que atenda à demanda dos adolescentes repletos de referências midiáticas. Ou ao partirem para seus estágios querendo estruturar conceitos de corpo e arte, enquanto as turmas queriam dançar o Bonde do Tigrão. Podia verificar isso também na naturalidade com que minha prima encarava o fato de seu filho de 5 anos, ainda não alfabetizado, saber a coreografia e as letras das músicas, em inglês, do filme High School Musical, a cujo DVD ele assistia pelo menos duas ou três vezes por dia. Podia também perceber o número de conhecidos que entraram no YouTube para se divertir, conferindo a Dança do Siri ou, mais recentemente, a dança do Ah Lelek Lek Lek ou do Gangnam Style.

OCORRÊNCIA 4: Um musical na favela do Rio de Janeiro./Cerca de 500 bailarinos de diferentes comunidades do Rio passaram pelos testes de dança./ Apenas 50 foram selecionados./Os 32 que compõem o corpo de baile ensaiaram durante seis meses as coreografias do longa-metragem de Lucia Murat:/ Maré: nossa história de amor.

Abertura do making off do filme, lançado no primeiro semestre de 2008.

Gradualmente comecei a perceber que nessas ocorrências e num bom número de outras que proliferam na mídia esboçavam-se lições de dança dos nossos tempos. Isso estava explícito tanto nas inúmeras orientações de como se dançar essa e aquela dança, como em outros tantos significados que parecem estar "colados" nestas regras, normas e orientações de se dançar numa particular política e economia de corpos que dançam na cena pósmoderna.

A ideia de lição está impregnada no imaginário da dança, seja na dança de salão ou no balé, nas danças folclóricas ou na street dance. As lições ensinam passos; cada movimento, relações entre os demais participantes da dança, bem como para quem a ela assiste. Do senso comum ao universo acadêmico a ideia de lição se colocava como uma possibilidade de operar, pelas questões que vinham inquietando-me, como a perspectiva trazida por Larrosa (1998) de entender a lição como uma chamada à leitura, a uma leitura do mundo, com a função de abrir um texto a uma leitura comum - operação que parecia a mídia estar fazendo com a dança.

O universo de significados expressos pela ideia de lições possibilitava abordar esta problemática e entender como antigas e novas lições passam a se articular na mídia. $\mathrm{O}$ que me interessava investigar e compreender eram os didatismos coreográficos, as exemplaridades de dança, as advertências para que os corpos dancem, as preleções sobre a dança e as repreensões aos corpos que não dançam, as leituras de mundo que estavam coladas nesse interesse pela dança.

Este investimento nos corpos que dançam (ou que podem e devem vir a dançar) estabelece modos de subjetivação complexos, sutis, sedutores. Essas transformações não se restringem ao uso dos novos aparatos tecnológicos. Enquanto bailamos com e na mídia, vamos nos constituindo enquanto sujeitos. Nessas danças e nesses jeitos de dançar, vão se "colando" sentidos culturais. Como me mexo? O que meu corpo revela? Como me coloco no espaço? Com quem danço? Onde danço? Onde estes passos poderiam levar-me?

Cabe ressaltar que comecei esta investigação de um lugar que era o de um pesquisador que teve na mídia uma porta para o mundo e para o conhecimento. Aprendi a dançar vendo televisão, descobri o fascínio dos musicais, a empolgação da disco dance, tive o estímulo de ser artista vendo um seriado na então rede Manchete, chamado Fama, e, mesmo recentemente, com a internet, tive acesso a inúmeros materiais (vídeos, textos, entrevistas). Essa tendência, contudo, não impediu que eu fosse percebendo as não menos potentes forças de subjetivação midiáticas a partir da dança, as tentativas de controle que promovem a homogeneização e a banalização da dança. Foi nesta tensão que transcorreu esta pesquisa. Por um lado, mantendo-me atento para não reproduzir apenas os discursos fundamentalistas que condenam a mídia como vilã que liquidifica identidades, subjetividades, lutas, crenças, corpos. Por outro lado, cuidando para que minha experiência e mesmo paixão pelos filmes musicais, telenovelas, videoclipes e internet não me furtassem de notar as tramas que envolvem a dança midiatizada em prol de um processo de globalização ávido por consumidores. Foi assim que este estudo procurou analisar e mostrar as lições de dança que a mídia vem configurando e suas estratégias de governamento ${ }^{2}$ (ou desgovernamento) dos corpos na pós-modernidade.

Neste sentido, alimentar-me com a perspectiva dos Estudos Culturais foi indispensável para me movimentar neste contexto e buscar compreendê-lo, sem a ideia de uma "grande teoria" que iluminasse meu objeto de pesquisa e permitisse descobrir tudo que nele se ocultava. A complexidade da problemática de pesquisa exigiu a articulação de enfoques teóricos e metodológicos que possibilitassem compreender a condição pós-moderna e seu vínculo inseparável com as novas tecnologias. E aqui acredito ser importante sublinhar mais uma vez que esta heterogeneidade não implica "qualquer coisa", como enfatiza Costa (2004). O que poderia ser fragilidade se coloca como condição necessária para os 
objetos com que se trabalha e, portanto, como rigorosa escolha. Escolha que exige constante avaliação, como também acontece em qualquer performance em dança. O constante tensionamento entre reflexão e investigação cria as possibilidades operacionais dos Estudos Culturais, o que fez Giroux (1997) alertar que este caminho exige mesmo uma práxis contradisciplinar.

Dessa forma, busquei avançar na articulação do conceito de midiatização e de poder sob a perspectiva de Michel Foucault, especialmente ao conceituar a noção de poder em movimento e não como uma instância estática e definidamente localizada. Afinal, "o poder está em toda parte não porque englobe tudo e sim porque provém de todos os lugares" (FOUCAULT, 1988, p. 89). O poder não está parado em dado local ou lugar e não estaria permanentemente nas mãos "daquele" que supostamente o detém e o utiliza com exclusividade. Pude, a partir desta base conceitual, pensar as estratégias de controle que não necessitam de uma força institucionalizada para se efetivar. Afinal, na sociedade de controle há

uma intensificação e uma síntese dos aparelhos de normalização de disciplinaridade que animam internamente nossas práticas comuns, mas, em contraste com a disciplina, esse controle estende bem para fora os locais estruturados de instituições sociais mediante redes flexíveis e flutuantes (HARDT; NEGRI, 2006, p. 43).

A partir dessas escolhas, optei por apostar na investigação da dança na mídia a partir das lições, o quê me permitiu perceber o processo de configuração da mídia como um dispositivo pedagógico ${ }^{3}$ para a dança. Dessa maneira, pude ampliar a investigação na direção das implicações da mídia na formação de sujeitos dançantes. O investimento nos corpos que dançam (ou que podem e devem vir a dançar) estabelece modos de subjetivação complexos, sutis, sedutores. Transformações que não se restringem ao uso dos novos aparatos tecnológicos. Enquanto baila-se com e na mídia, vai-se constituindo certos tipos de sujeitos. Nestas danças e nestes jeitos de dançar, vão se "colando" sentidos culturais, instruções, orientações de condutas e comportamentos. E neste movimento, aprender dança vai se tornando uma importante tarefa cultural, cada vez mais valorizada.

\section{O DESAFIO METODOLÓGICO PARA UM CORPUS DE CORPOS DANÇANTES}

Metodologicamente, foi necessário estar atento à singularidade do problema de pesquisa e à construção de estratégias adequadas, como as apontadas por Efendy Madonado (2004). Para isso, busquei articular perspectivas especialmente em autores e obras como
O antropólogo como autor (GEERTZ, 2005), De la investigación audivisual (BUXÓ, 1999), bem como nas inspiradas e provocativas propostas de Nicolás Lorite Garcia quanto à proposição de uma observação casual. Esses caminhos investigativos ganharam uma orientação na sensível e apurada percepção de Simon Gottschalk (1998) ao propor uma etnografia pós-moderna que alerta a questões como a de que "a criatividade, a flexibilidade e a adaptação ética ao campo deveriam contar mais do que a submissão a regras produzidas alhures por outra pessoa em outro tempo e com propósitos diferentes" (p. 208).

A pesquisa impôs, portanto, um percurso repleto de desafios aos quais precisei estar atento e encontrar estratégias singulares de observação, sistematização e análise. O primeiro foi de mapear o que chamei de ocorrências de dança na mídia. Assim, fui estabelecendo um corpus de pesquisa a partir da minha própria observação cotidiana: matérias de jornais (sobre bailarinos, sobre muitos tipos de danças, sobre políticos ou mulheres grávidas que dançam); filmes (do resgate de clássicos como Cantando na Chuva a novas produções como Cisne Negro ou Burlesque); comercias (de bancos a de produtos de limpeza); trechos de programas de auditório televisivos (com quadros como Dança dos Famosos, Dança da Galera, Dança Gatinho); programas de televisão exclusivamente de dança como Se ela Dança Eu Danço; aberturas e cenas de telenovelas; videoclipes dos mais diversos gêneros (hip hop, sertanejo, pagode, pop music, funk) e artistas como Madonna, Shakira, Ivete Sangalo, Chris Brown); conteúdo de sites e blogs e ainda brinquedos (como Barbie Bailarina ou os tapetes de dança) e jogos eletrônicos (Just Dance, Dance Paradise, Dance Masters).

Essas ocorrências foram sendo registradas num diário de campo virtual, em inúmeros arquivos de texto, imagens e sons, em pastas que proliferavam no computador: comerciais de televisão, filmes recentes, filmes antigos, sites, blogs, programas de auditório, telenovelas, seriados, catálogos de brinquedos eletrônicos, entre muitas outras. Gradualmente, busquei sistematizar esse material que revelou um volume intenso de dança no universo midiático, que crescia semanalmente, atualizando-se com muita rapidez.

A opção por não escolher um produto ou mídia para estudar mostrou-se pertinente. A dança na mídia revela um constante atravessamento de gêneros, suportes e linguagens de produção, modos de circulação e consumo que tornava quase impossível pensar no seu entendimento em separado. É tanta informação e tão rápida a circulação, que é assim que somos interpelados, aos pedaços e por quase todos os lados. O lançamento de um filme ou de um novo programa de televisão costuma ser seguido e mesmo antecedido por reportagens em jornais e revistas ou em 
site específico do filme, aparece nos comentários de blogs pessoais, aparecem trechos disponibilizados na rede e até mesmo podem se transformar em jogos de videogame. Este universo se configura num emaranhado de produtos e modos de distribuição que se relacionam, se alimentam ou mesmo se contrapõem.

Foi se desenhando, dessa forma, um circuito cultural no qual eu percebia singulares políticas dos corpos que dançam com e na mídia. Um circuito dinâmico e multifacetado que envolvia produção, consumo e representações que apontavam para uma complexa rede de relações de poderes e saberes. Um circuito com suas especificidades, criando e valendo-se de inúmeras práticas de dança e discursos sobre dança. Foi preciso estar atento a como se configura essa nova produção midiática de dança nas suas diferentes linguagens e suportes tecnológicos. A possibilidade de se ter um close de nádegas que rebolam ou um slown motion do sinuoso quadril que ondula estabelece outra experiência em relação àquele corpo que dança. Assim a experiência de dança é redimensionada ao ser praticada sobre um tapete luminoso que pisca, toca música e dá instruções de como conduzir a coreografia sob o foco de luzes e plateia. Essas experiências estabelecem um novo jeito de vivenciar a dança, que inspirado por Muniz Sodré (2002), denominei de um etos de dança midiatizada, nutrido pelas pistas de autores como Frederic Jameson (1996) e David Harvey (1993) ao se deterem nas singularidades da pósmodernidade.

As lições de dança na mídia ganham, desse modo, um novo contorno, no qual visibilidade, performance e espetacularidade são elementos determinantes para estabelecer o que vai sendo "ensinado" e como se vai "ensinando". A ideia tradicional de estudar a lição, associada a um ato penoso, ganha com a mídia um valor simbólico de divertimento e sedução. A função pedagógica se mantém, mas não é anunciada, nem explicitada; é diluída num grande show no qual discursos e práticas vão buscando estabelecer condutas e comportamentos, convidando continuamente para entrar nesse show e, consequentemente, nos padrões que este show solicita.

E se essas lições mudam suas estratégias pedagógicas, também ampliam o seu alcance. As lições de dança midiatizada possibilitam que sejam proferidas para uma audiência que extrapola qualquer ideia tradicional de uma sala de aula ou de uma sala de conferências. Discursos e práticas midiáticos em torno da dança são proferidos para a multidão espalhada pelo planeta. Shows ou cerimônias assistidos simultaneamente em dezenas e centenas de países, por milhões de espectadores, milhões de espectadores nos cinemas, milhões de DVDs vendidos, milhões ou bilhões de internautas navegando na rede. As lições midiáticas potencializam não apenas na sedução de discursos e práticas, como também no número de participantes deste baile.

Além disso, foi possível reconhecer a multiplicidade de artefatos midiáticos que configuram estas lições. Nelas, a dança está presente. Ssensível às diferentes condições que cada tecnologia, linguagem e formato estabelecem para a dança na mídia, comecei a perceber quais eram então as práticas e discursos mais recorrentes neste universo e que tipo de "ensinamentos" quanto à dança estavam configurando.

\section{Percebendo lições}

Com isso, não busquei esgotar as possíveis lições que estão presentes na mídia, mas mostrar as que parecem receber um maior investimento, seja pela quantidade, pela amplitude ou pela insistência na direção de certos sentidos culturais.

Dessa forma, optei por me dedicar à investigação de dez lições centrais observadas, a partir da da análise e sistematização de um amplo corpus composto de filmes, sites, jogos eletrônicos, revistas, blogs, programas televisivos, entre outros:

- Lição 1 - Há uma dança sob medida para você

- Lição 2 - Todo mundo deve entrar na dança

- Lição 3 - Você pode dançar a toda hora e em todo lugar

- Lição 4 - É preciso (re)mexer muito, sem parar

- Lição 5 - Dançando, o corpo não mente

- Lição 6 - A dança seduz

- Lição 7 - Dança é festa

- Lição 8 - Quer dançar? A mídia vai te ensinar

- Lição 9-A dança faz da vida um permanente espetáculo

- Lição 10 - Com a dança você vai "se dar bem"!

De saída, pude perceber na mídia um investimento contínuo e multifacetado quanto à solicitação para que todos dancem. E isso se dava a partir de uma série de discursos e práticas de dança na mídia que estabelecem as condições necessárias para tentar mobilizar as singularidades dispersas na multidão.$^{4} \mathrm{~A}$ primeira condição que identifiquei foi a de uma ampla oferta midiática de tipos de danças. Uma oferta que acaba por também orientar para que cada um deva encontrar a(s) sua(s) dança(s). Esta variedade dançante procura a adesão e/ou captura de todas as faixas etárias, todas as classes, todas as etnias, etc. Tal característica é marcante, por exemplo, no quadro Dança dos Famosos, da TV Globo, que incluiu na edição de 2008 apresentações de bolero, merengue, gipsy, forró, lambada, passo doble, maxixe, gafieira, hip hop e tango. Muitos "idiomas corporais" devem fazer parte do cardápio coreográfico que garante espectadores que conhecem ou admiram mais um ou 
outra dança, ou que ainda passam a ser apresentados a danças que desconheciam.

Além destas danças, nominadas e "reconhecidas" seja por seu estilo ou origem geográfica ou étnica, é importante observar o grande número de danças produzidas pelos próprios internautas seja tentando reproduzir danças que circulam no YouTube, parodiando-as ou mesmo criadas e inventadas, como a "dança do Rodrigo" e a "dança da Laura". Há uma extrema privatização da dança na mídia. Cada um pode ter a própria dança, com a sua assinatura. Tango, funk, dança de rua, dança da minhoca, samba, forró, Bhangra, pole dance, salsa, zouk, dança da Maria, dança do João e outras centenas de danças podem ser identificadas em filmes, sites, blogs, telenovelas, documentários, além de muitos outros artefatos midiáticos. E é com um vasto e variado arsenal dançante que a mídia vai operando como um grande supermercado coreográfico com artigos de primeira necessidade (as danças da moda, do momento), com artigos importados (que dão status) e com promoções (aquelas de que se abre mão da qualidade pelo preço baixo) e com artigos tradicionais (sem maior atrativo, mas bem conhecidos e confiáveis). O importante é sempre ter uma dança sob medida para cada um entrar na dança.

Como diz a letra da canção de Bob Sinclair, Rock This Party: "Everybody dance now", se há uma dança para cada sujeito, que todo mundo dance agora. No videoclipe, um menino e duas garotas se revezam em personagens das mais diferentes épocas (anos 60, 70, 80, 90) e estilos musicais (rock, reggae, pop, disco, heavy metal), mostrando como todos podem e devem entrar na dança, independente do seu estilo, faixa etária ou gênero. A segunda lição de dança que percebo na mídia se esboça desta maneira: todo mundo deve entrar na dança. E, para tal lição se mostrar efetiva, é preciso "democratizar", para que um maior e mais amplo contingente de indivíduos possa aderir à dança.

E, se muitas danças estão habitando a mídia, muitos são os corpos que passam a também entrar na dança. No baile midiático dança o artista que dança, dança o artista que nunca dançou, dança a gordinha, dança a "sarada", dança a velhinha, dança o caipira, dança a criança, dança o cadeirante, dança quem leva jeito, dança quem não leva, dança a high society, dança a periferia. Ao longo de várias edições do programa Dança dos Famosos, por exemplo, estiveram representados vários segmentos profissionais e étnicos, vários tipos físicos, um amplo espectro geracional que inclui: homens e mulheres; brancos, mulatos e negros ; belezas-padrões do universo da moda e das passarelas; jovens vigorosos e cantores desajeitados. Francisco Couco foi para pista de dança com seus 75 anos, Sérgio Loroza, com seus 175 quilos e Oscar Schimidt, com seus 2,04 metros. Dançam também o empresário e o operário, a dona de casa e a empregada, dança até o jogador de vôlei, de futebol e de basquete.

No desenho animado Shrek 2, a cena final é Shrek Karoke Dance Party. Nela o ogro sugere: "Levantem e dancem a música" e passamos então a ver Robin Hood e seus ladrões dançarem YMCA e a coreografia coloca a dançar Os Três Porquinhos, Branca de Neve, Pinóquio, dragões e ursos. E dançam também o leão, a zebra, a girafa e a hipopótamo, além de lêmures e pinguins, em Madagascar. Inclusive os pinguins dançam muito (e muito bem), em Happy Feet. Nos comerciais televisivos, nos programas de auditórios, nos filmes de Hollywood, nos sites ou no Youtube as imagens são exemplares, todos estão lá, sempre dançando.

E a mídia vai mais longe, nos seus ensinamentos. Se podem surgir dificuldades de praticar ou assistir à dança "escolhida", a mídia também orienta para as inúmeras possibilidades que a tecnologia oferece para superar tais obstáculos, numa variedade de espacialidades e temporalidades. As rotinas do sujeito, dessa forma, podem ser cobertas, desde que acorda até durante seu sono. A matéria de encerramento do Fantástico de 14 de setembro de 2008 mostrou pessoas que dançam no seu local de trabalho, inclusive um grupo de funcionárias dançando em cadeiras giratórias e rapazes rebolando ao som de Sidney Magal. O destaque de abertura da matéria era do soldado que aparecia dançando em um quartel da Base Comunitária de Segurança do Imirim, zona norte de São Paulo. ${ }^{6}$ A mídia sinaliza que o contexto familiar, privado, profissional, escolar, é também para se dançar.

Esta dança a que todos devem se entregar, por sua vez, deve ser contínua, intensa, vertiginosa. Há uma solicitação que, na dança, todo participante se (re)mexa muito. E esta solicitação não é consequência de todos entrarem na dança, pois se pode entrar numa dança calma, de pequenos movimentos, suave, mais intimista, com direito a eventuais pausas. Mas a mídia parece estabelecer uma solicitação por um constante desempenho corporal acelerado, extrovertido, exacerbado, ininterrupto. Isso aparece também em videoclipes como o de Madonna Give it 2 me. A letra diz: "Não tente me fazer parar/Eu não preciso tomar fôlego/Posso seguir sem parar/Quando as luzes se apagam/E não há ninguém por perto/Eu continuo sem parar". E é o que sugere também o videoclipe One more time, do grupo Daft Punk, ${ }^{7}$ que profere: "Mais uma vez, nós vamos celebrar/ oh sim, tudo certo, não pare de dançar". Os apelos neste sentido são inúmeros na produção da música $p o p$ contemporânea, mas não se restringem a este universo. No Big Brother Brasil, os participantes devem participar de festas pelo menos duas vezes por semana, sempre com uma central pista de dança. As festas chegam a durar mais de oito horas. 
Esses corpos convocados a dançar e a dançar muito estão não apenas se consumindo de tanto dançar, mas também confessando segredos, numa lição midiática que enfatiza o fato de que o corpo que dança não mente. A dança se configura no espaço midiático como um discurso privilegiado mais verdadeiro do que o discurso verbal. E desta forma, as confissões dançantes vão se tornando uma importante maneira de governamento e da interpelação de sujeitos comprometidos em um regime de verdade. Como traduz o videoclipe de Shakira, Hips don't lies:"Então seja sábio e continue/A ler os sinais do meu corpo/Eu estou aqui nesta noite/Você sabe, meus quadris não mentem".

Mas o "conteúdo programático" das lições de dança na mídia inclui outros atributos que precisam ser reafirmados, como a lição de que a dança seduz. Isso aparece tanto na ênfase nos sensuais corpos femininos, de maneira geral, "turbinados" e requebrantes, tanto das estrelas da música pop como Madonna e Beyoncé, como no da Mulher Melancia. A carne torna-se mais apetitosa com o funk, com o carnaval, com o hip hop. E não apenas a carne feminina, mas também a masculina, de tórax e abdomens nus e calças justas que marcam volumes frontais e traseiros de bailarinos.

Como são muitos os contextos associados à dança pela mídia, há de se perceber a lição que recorrentemente vem vinculando esse cenário à noção de festa. Enquanto se preserva o caráter celebrativo dos corpos que se encontram para dançar, há uma clara tentativa de padronização, de controle de como a festa deve acontecer. No YouTube, para a pesquisa das palavras "festa" e "dança" aparecem cerca de 14 mil vídeos, nos quais a dança aparece em contextos como o da Festa das Nações, Festa Junina, Festa do BBB, Festa Country, Festa da Família, Festa da Uva, Festa de Casamento, Festa Rave. No blog intitulado Aula de Dança para festas, o texto explicita a lição:

Sem dúvida falando sobre o mundo inteiro a parte, sobre todas aquelas pessoas que foram a pelo menos a uma festa, muitos não aproveitaram da forma que podiam certo? Com certeza, ficaram sentadas no sofá a festa toda, só olhando o restante da turma dançando, isso é inevitável, mas com este vídeo você aprenderá a dançar como nunca. ${ }^{8}$

Inúmeros videoclipes também se desenvolvem em torno de um grupo de pessoas que está dançando em uma festa. Em Get me boied, Beyoncé chega a uma festa vip com um grupo de garotas e, com sua dança, anima o evento.

Outro conteúdo dessas aulas midiáticas de dança é auto-referente. A mídia pode dar conta de ensinar como se comportar nesse baile todo. Nas tramas que envolvem saber/poder, a mídia cria um forte aparato pedagógico que oferece inovadoras alternativas para quem se dedicar a estas lições. "Quer dançar, quer dançar, o Tigrão vai te ensinar". O trecho da canção do Bonde do Tigrão traduz de certa maneira essa outra lição de dança midiatizada. A mídia não somente ensina que é preciso aprender a dançar e dançar. A mídia ensina que a mídia é lugar de educar os corpos que dançam e cria e apresenta específicos modos para tal aprendizado. Letras, programas, sites, vídeos, bônus nos DVDs, intervalo da novela, jogos eletrônicos. São inúmeras as estratégias para ensinar quem quer dançar e de enfatizar quem são os novos "professores" de dança, bem como oferecer novas condições de se aprender dança com a mídia.

E todo esse universo dançante deve fazer parte de um constante processo de espetacularização, apontando para uma estetização contínua da vida, o que estaria atrelado a tramas de uma ordem global que valoriza a performance e a encenação. A lição prescreve que a vida deve ser vivida como um espetáculo. Todo lugar, toda hora é hora de dançar. O cotidiano deve ser um eterno show. Para isso, uma estetização exacerbada passa a também fazer parte do cotidiano. Um cotidiano habitado por sujeitos sempre prontos para entrarem em cena e dar início ao espetáculo ou deixar o espetáculo fazer parte das suas ações mais comuns e ordinárias.

Para dar especial relevo a todas as demais lições, a mídia procura vincular a dança às mais variadas situações bem-sucedidas, seja associando a dança com o êxito pessoal, financeiro e/ou social. A ideia recorrente em inúmeros artefatos midiáticos é a de que por meio da dança podemos ser pessoas melhores, seja na esfera pessoal, econômica, social e até mesmo política (como na ênfase que noticiários vêm dando a presidentes de várias nações habilitados a bailar).

A dança passa a ser uma produtiva estratégia para inclusive ganhar adeptos e "salvar almas". O texto do site Corpo Santo sinaliza esta transformação:
Quero terminar com o Salmo 150 que diz: 'Todo ser que respira louve ao Senhor. Aleluia!'. A adoração com danças não é exclusiva de bailarinos e levitas, dançar é bailar, dança é movimento, antes de dançarmos com o corpo, dançamos com a alma. Basta um simples bater de pés e você pode tornar isso em dança, lembra do Sapateado? Portanto adore ao Senhor com sua dança! ${ }^{9}$

Em matéria do caderno DonnaZH, publicado em de 10 setembro de 2006, o título não apenas da matéria, mas da capa do suplemento era: Se eles dançam eu danço. O texto destacava que as aulas de dança de salão estavam mais populares do que nunca, além de apresentar os benefícios que tal prática oferece. Eram apresentados seis motivos para "cair na dança":

- para arrasar na pista;

- para se divertir;

- para fazer companhia; 
- para manter a forma e relaxar;

- para impressionar as gurias;

- para espantar o sedentarismo.

É preciso compreender que essas lições não aparecem de forma isolada, mas se retroalimentam, se contradizem, estabelecem vínculos óbvios e outros absolutamente inéditos. A lição que educa para todos entrarem na dança, pode educar também para uma dança frenética e/ou educar para o corpo não esconder seus segredos enquanto dança. A dança que seduz, reafirma a festa e a espetacularidade e os benefícios da sensualidade dançante.

As dez lições de dança que eu destaco, indicam, contudo a formação não apenas de alunos que conheçam a dança e saibam dançar, elas são lições que vão constituindo um certo tipo de sujeito. E, no caso, ser um sujeito do seu tempo parece ser um sujeito dançante, que carrega atributos apresentados como indispensáveis para garantia de saúde, felicidade, prosperidade, conquista, sedução, status social, sucesso, trabalho, dinheiro. A cultura se coloca, dessa maneira, como uma forma de penetrar, conforme salientou Hall (1997), em cada recanto da vida social contemporânea. E as estratégias de governamento passam a se valer com maestria desse recurso inesgotável e polimorfo, que é o da dança midiática.

\section{O COMPLEXO BAILE MIDIÁTICO PÓS-MODERNO}

Com a dança, a mídia vai fazendo da celebração festiva do corpo uma alternativa de controle. Esse caráter gerencial é uma das facetas que a dança midiatizada permite perceber. Contudo, buscar compreender a dança na mídia, e as estratégias de governamento dos corpos, exige "admitir um jogo complexo e instável em que o discurso pode ser, ao mesmo tempo, instrumento e efeito de poder, e também obstáculo, escora, ponto de resistência ou ponto de partida de uma estratégia oposta" (FOUCAULT, 1988, p. 96). Em meio à padronização de certos tipos de corpos e danças que proliferam há espaço para inventividade, inconformidade e desvios também.

Afinal, as improvisações dos concursos de Pump it $U p$ vão além da mera mecanização de passos, resultando em complexas e criativas coreografias, ainda que realizadas em uma máquina. Nos videoclipes, por exemplo, há também espaço para obras criativas e instigantes, como Praise You (1998). Nele, o diretor Spike Jonze ${ }^{10}$ resolveu encarnar o líder de uma companhia de dança urbana denominada The Torrance Community Dance Group. O grupo reúne corpos nada padrão dos encontrados nos videoclipes, como uma senhora de meia-idade, um nerd e senhores que parecem saídos de uma aula de ioga. E, além de tudo, dançam na calçada, incomodando os consumidores de uma fila para compra de ingressos.
Perceber estas perturbações que surgem numa possível uniformidade da dança na mídia e nas suas lições é começar a se debruçar sobre questões como as de

que poderes é preciso enfrentar e quais as nossas possibilidades de resistência hoje, quando não podemos nos contentar em dizer que as velhas lutas não valem mais? E será que não estamos assistindo, participando da 'produção de uma nova subjetividade'? As mutações do capitalismo não encontram um 'adversário' inesperado na lenta emergência de um novo Si como foco de resistência? (DELEUZE, 1988, p. 123)

A emergência de novos sujeitos parece ser uma condição inalienável de uma trama de saberes e poderes que se baseia na polimorfia, na flexibilização e na descentralidade. A mídia acaba criando estratégias para capturar, mas a mulditão também se vale da lógica da mídia para afirmar, produzir, criar, legitimar.

É verdade que o capitalismo manteve como constante a extrema miséria de três quartos da humanidade, pobres demais para a dívida, numerosos demais para o confinamento: o controle não só terá que enfrentar a dissipação das fronteiras, mas também a explosão dos guetos e favelas (DELEUZE, 1992, p. 224).

Pensar a multidão planetária, obriga-nos a pensar também no excedente, no incontrolável, do des(governável). Afinal, foi assim que a mídia que busca indicar condutas possibilitou que uma dança da periferia se projetasse e, mais do que isso, se legitimasse. O baile midiático e as lições que nele se configuram estão repletas de ambiguidades geradas por discursos e práticas que fazem da mídia um poderoso dispositivo pedagógico. Tem-se um mercado cultural que precisa cada vez mais ampliar sua rede de consumidores e, para isso, oferece um número cada vez maior de produtos para dar conta da multidão globalizada. Este movimento promove o surgimento e divulgação de novas danças, de muitas matrizes coreográficas que ficavam à margem ou em redutos e guetos de menor abrangência. Para o bem e para o mal, esse processo acaba gerando o deslocamento de muitas danças de seus contextos originais e a combinação de elementos de várias danças, às vezes com vitalidade criativa, às vezes como uma simples colagem que reproduz estereótipos de uma pretendida fusão de culturas.

Como apontou Sibilia (2008), talvez o fenômeno midiático esteja encarnando uma mistura inédita, ao mesmo tempo que promove a "explosão criativa" e uma extraordinária democratização, também promove uma eficaz instrumentalização das forças vitais, capitalizadas a serviço do mercado. 
Percebo esse constante jogo de poderes em movimento, mas acreditando no corpo fugidio que transita por entre as malhas do controle midiático.

Qualquer um pode tentar capturar o vento, o mar, a terra, mas eles sempre serão mais do que podemos apreender. Do ponto de vista da ordem e do controle políticos, assim, a carne elementar da multidão é desesperadamente fugidia, pois não pode ser inteiramente enfeixada nos órgãos hierárquicos de um corpo político (HARDT; NEGRI, 2005, p. 251).

Mergulhar no universo da dança midiatizada foi uma transformadora experiência para começar a entender a dimensão política da dança na cultura contemporânea e reafirmar a tendência de constituir sujeitos dançantes na pós-modernidade. Por isso, ao buscar traduzir aspectos centrais de uma pesquisa exaustiva, ampla e apaixonante, quis estar atento à lição de Barthes (1988) e buscar: um pouco de sabedoria e o máximo de sabor possível, acreditando que me permiti dançar bastante neste percurso e me perder também nesta dança, já que

há uma idade em que se ensina o que se sabe; mas surge em seguida uma outra em que se ensina o que não se sabe: a isso se chama procurar. Chega agora, talvez, a idade de uma outra experiência: a de desaprender, de deixar germinar a mudança imprevisível que o esquecimento impõe à sedimentação dos saberes, das culturas, das crenças que atravessamos" (BARTHES, 1988, p. 41-42).

Espero ter desaprendido bastante e ter deixado germinar imprevisíveis mudanças.

\section{REFERÊNCIAS}

BARTHES, Roland. Lição. Lisboa: Edições 70, 1988.

BUXÓ, Maria Jesús. “...que mil palabras”. In: BUXÓ, Maria Jesús; DE MIGUEL, Jesús M. (Ed.). De la investigación audiovisual: fotografía, cine, vídeo, televisión. Barcelona: Proyecto A Ediciones, 1999. p. 1-22.

COSTA, Marisa Vorraber. Estudos Culturais em educação: mídia, arquitetura, brinquedo, biologia, literatura, cinema. Porto Alegre: Ed. Universidade/UFRGS, 2004.

COSTA, Marisa Vorraber. A escola rouba a cena - um início de conversa. In: COSTA, Marisa Vorraber (Org.). A escola tem futuro? 2 ed. Rio de Janeiro: Lamparina, 2007. p. 11-21.

DELEUZE, Gilles. Post scriptum sobre as sociedades de controle. In: DELEUZE, Gilles. Conversações. Rio de Janeiro: 34 Letras, 1992. p. 219-226.

DELEUZE, Gilles. ¿Que és un dispositivo? In: BALBIER, Etiene. Michel Foucault, filósofo. Trad. Wanderson Flor do Nasciemento. Barcelona: Gedisa, 1990. p. 155-161. Disponível em: <http://www.unb.br/fe/tef/filoesco/foucault/art14.html>. Acesso em: 25 maio 2008.
FOUCAULT, Michel. História da sexualidade I: a vontade de saber. 10. ed. Rio de Janeiro: Graal, 1988.

FOUCAULT, Michel. Microfísica do poder. Rio de Janeiro: Graal, 1990.

FOUCAULT, Michel. Sobre a genealogia da ética: uma revisão do trabalho. In: RABINOW, Paul; DREYFUS, Hubert. Michel Foucault: uma trajetória filosófica: para além do estruturalismo e da hermenêutica. Rio de Janeiro: Forense Universitária, 1995. p. 253-278.

GEERTZ, Clifford. O antropólogo como autor. Rio de Janeiro: Editora UFRJ, 2005.

GIROUX, Henry A. Os professores como intelectuais: rumo a uma pedagogia crítica da aprendizagem. Porto Alegre: Artes Médicas, 1997.

GOTTSCHALK, Simon. Postmodern sensibilities and ethnographic possibilities. In: BANKS, Anna; BANKS, Stephen P. Fiction and social research: by ice or fire. Trad. Ricardo Uebel. London: Altamira Press, 1998. p. 206-226.

GREEN, Bill; BIGUM, Chris. Alienígenas na sala de aula. In: SILVA, Tomaz Tadeu da (Org.). Alienígenas na sala de aula: uma introdução aos Estudos Culturais em educação. Petrópolis: Vozes, 1995. p. 208-243.

HALL, Stuart. A centralidade da cultura: notas sobre as revoluções de nosso tempo. Educação \& Realidade, Porto Alegre, v. 22, n. 2, p. 15-46, jul.-dez. 1997.

HARDT, Michael; NEGRI, Antonio. Multidão: guerra e democracia na era do império. Tradução: Clóvis Marques. Rio de Janeiro: Record, 2005.

HARDT, Michael. Império. 8. Ed. Rio de Janeiro: Record, 2006.

HARVEY, David. A condição pós-moderna. Trad. Adail Sobral e Maria Estela Gonçalves. São Paulo: Loyola, 1993.

JAMESON, Fredric. Pós-modernismo: a lógica cultural do capitalismo tardio. São Paulo: Ática, 1996.

KELLNER, Douglas. $A$ Cultura da mídia. Trad. Ivone Castilho Beneditti. São Paulo: EDUSC, 2001.

LARROSA, Jorge. Tecnologias do eu e educação. In: SILVA, Tomaz Tadeu da. O sujeito da educação: estudos foucaultianos. Petrópolis: Vozes, 1994. p. 35-86.

LARROSA, Jorge. Pedagogia profana: danças, piruetas e mascaradas. Porto Alegre: Contrabando, 1998.

LORITE GARCIA, Nicolas. La observación casual: uma proposta para el estudio de las transformaciones sociomediáticas. Ponencia para el Encuentro Internacional de Investigadores de la Comunicación, Alaic, Santiago do Chile, 2000.

MALDONADO, Efendy. Produtos midiáticos, estratégias, recepção: a perspectiva transmetodológica. Ciberlegenda, Rio de Janeiro, n. 9, p. 1-15, 2002. Disponível em: <http://www.uff. br/mestcii/efendy2.htm>. Acesso em: 20 abr. 2004.

MARTÍN-BARBERO, Jesús. Oficio de cartógrafo: travesías latinoamericanas de la comunicación en la cultura. Chile: Fondo de Cultura Económica, 2002.

NELSON, Cary; TREICHLER, Paula A.; GROSSBERG, Lawrence. Estudos Culturais: uma introdução. In: SILVA, Tomaz Tadeu da (Org.). Alienígenas na sala de aula: uma 
introdução aos Estudos Culturais em educação. Petrópolis: Vozes, 1995. p. 7-38.

SIBILIA, Paula. O show do eu: a intimidade como espetáculo. Rio de Janeiro: Nova Fronteira, 2008.

SODRÉ, Muniz. Antropológica do espelho: uma teoria da comunicação linear e em rede. Petrópolis: Vozes, 2002.

VEIGA-NETO, Alfredo. Coisas de governo... In: RAGO, Margareth; ORLANDI, Luiz B. Lacerda; VEIGA-NETO, Alfredo (Org.). Imagens de Foucault e Deleuze: ressonâncias nietzschianas. Rio de Janeiro, DPA, 2002. p. 13-34.

\section{Notas}

${ }^{1} \mathrm{O}$ entendimento do fenômeno da mídia aqui assumido dialoga com a perspectiva de Muniz Sodré (2002) de compreender a mídia como uma tecnocultura, implicando-a na transformação das formas tradicionais de sociabilização a partir de uma "nova tecnologia perceptiva e mental" (SODRÉ, 2002, p. 27), que reorganiza as possibilidades dos sujeitos se perceberem, perceberem o mundo e articularem suas relações. Portanto, alinhando-me a esse viés conceitual, que também ressoa em autores como Kellner (2001) e Martín-Barbero (2002), busco entender como está se processando o redesenho das experiências atravessadas pela mídia. Redesenho que vem produzindo uma nova maneira de vincular-se, de reconhecer-se, de estranhar-se, de administrar-se e inclusive de se educar, ou seja, o fenômeno da mídia entendido como um novo e diferenciado investimento sobre os indivíduos na contemporaneidade.

2 Optei, portanto, por usar o termo governamento, por estar tratando "a questão da ação ou ato de governar" (VEIGA-NETO, 2002, p. 19). Governar não na esfera restrita das ações de estadistas, mas no que se refere ao ato de dirigir indivíduos e/ou grupos, orientar suas condutas, controlar seus atos. Ao operar com o conceito de governamento, acredito poder pensar não apenas as estratégias disciplinares, mas também as de controle, e, assim, combinar a perspectiva foucaultiana e deleuziana, potencializando a análise dos corpos (des)governados que bailam na mídia.

$3 \mathrm{O}$ conceito de dispositivo remete aqui a "estratégias de relações de força sustentando tipos de saber e sendo sustentadas por elas" (FOUCAULT, 1990, p. 246). Autores como Larrosa (1994) têm inclusive apontado para o desenho de dispositivos pedagógicos, entendido como "qualquer lugar no qual se constitui ou se transforma a experiência de si. Qualquer lugar no qual se aprendem ou se modificam as relações que o sujeito estabelece consigo mesmo" (LARROSA, 1994, p. 57).

${ }^{4} \mathrm{O}$ conceito de multidão trabalhado por $\mathrm{M}$. Hardt e A. Negri é pertinente para pensar nos sujeitos não como povo, nação, massa. Um conceito que trafega pela condição contemporânea de indivíduos frente a fronteiras abertas e móveis; indivíduos rapidamente e constantemente conectados; indivíduos organizados politicamente de maneira descentralizada; indivíduos que mais do que uma identidade nas suas singularidades, compartilham algo em comum. O comum que "permite comunicar-se e agir em conjunto" (HARDT; NEGRI, 2005, p. 14)

5 Gíria brasileira para designar o corpo em forma pela ginástica e/ou musculação.

6 Disponível em: <http://fantastico.globo.com/Jornalismo/FANT/0,„MUL 751525-15605,00.html>. Acesso em 12 abr. 2009.

7 Dupla francesa responsável por alguns dos maiores sucessos do segmento da música eletrônica.

8 Disponível em: <http://www.blogers.com.br/aula-de-danca-para-festas/> Acesso em 23 mar. 2009.

9 Disponível em: $<\mathrm{http}: / /$ www.corposanto.com/materias.asp?Secao=Mate rias $\&$ SubSecao $=7 \&$ chave $=9>$.

${ }^{10}$ Cineasta que vem se destacando na produção de filmes dos Estados Unidos com obras irreverentes como Quero ser John Malkovich (Being John Malkovich, 1999) e Adaptação (Adaptation, 2002)

Artigo recebido em setembro 2014

Aprovado em março 2015. 